\title{
Study Start Date
}

National Cancer Institute

\section{Source}

National Cancer Institute. Study Start Date. NCI Thesaurus. Code C69208.

The date on which a study began. 